\title{
调整国家自然科学基金申请代码，优化大气学科资助布局
}

刘哲 ${ }^{1 *}$, 丁爱军 ${ }^{2}$, 张人禾 ${ }^{3}$

1. 国家自然科学基金委员会地球科学部, 北京 100085 ;

2. 南京大学大气科学学院, 南京 210023 ;

3. 复旦大学大气与海洋科学系/大气
* 联系人, E-mail: liuzhe @ nsfc.gov.cn

作为国家自然科学基金的改革试点, 大气学科积极落 实新时代科学基金资助导向, 主动对接地球科学部倡议的 “宜居地球”顶层战略设计. 基于明确的“问题导向”, 在科 学界的大力支持下, 通过开展资助战略研究, 集思广益形 成了 2020 年度申请代码设置方案, 并通过地球科学部专 家咨询委员会论证后予以实施, 助力构建“源于知识体系 逻辑结构、促进知识与应用融通的学科布局” ${ }^{\text {[1] }}$.

考虑到申请代码在表述上具有高度概括性的特点, 本 文从申请代码调整的背景、思路以及代码结构和内涵等方 面进行了专门解读. 以利于广大科研人员及时了解代码调 整过程以及调整可能引起的学科布局变化, 更好地指导科 研人员更为便捷、准确地选择项目申请领域.

\section{1 学科发展背景}

在当前新一轮科技革命蓬勃兴起的背景下, 新的科学 研究范式正在形成, 各学科间的交叉融合更加紧密 ${ }^{[1 \sim 3]}$. 为更好地顺应科技发展趋势, 满足国家和人类社会发展重 大需求, 应对全球挑战, 作为基础研究的主要资助机构之 一, 国家自然科学基金委员会(简称基金委)顺应这一潮流, 积极开展了各项改革工作, 不失时机地提出了 “明确资助 导向”、“完善评审机制”、“优化学科布局”三大改革任务 ${ }^{[1-3]}$. 在这三大改革任务中, 学科申请代码调整是“优化学科布 局”任务的重要组成部分和切人点. 基金委明确提出了申 请代码修订工作的重要原则: “提高申请代码的包容性和 覆盖面, 通过较粗的申请代码结构尽可能涵盖更多的研究 方向. 鼓励设置跨科学部申请代码, 加强对跨学科大交叉 研究的支持”[4].

作为对改革的积极响应, 基金委地球科学部提出了以 “宜居地球的过去、现在与未来”(简称“宜居地球”) 为顶层设 计的地球科学“十四·五”发展战略规划. “宜居地球”旨在从 “深地”、“深海”和“深空”3 个方面研究驱动地球宜居性演变 的“引擎”, 推动以“地球系统科学”引领地球科学研究范式 的转变, 搭建 “三深一系统”的资助构架. 地球科学部亦明 确要求下设各学科优化调整申请代码, 使申请代码与学部 “三深一系统”顶层设计有效对接.

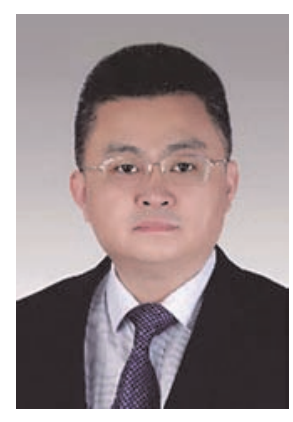

刘哲国家自然科学基金委员会 研究员, 从事大气学科项目管理和 资助战略研究等工作。

大气科学是研究地球和行星大气中发生的各种现象 及其变化规律, 进而利用这些规律为社会服务的学科 ${ }^{[1,5 ~ 7]}$. 《国家自然科学基金项目指南》明确指出 ${ }^{[1]}$, 大气学科不 仅研究大气圈层本身, 而且延伸到大气圈层与其他圈层的 相互作用. 大气学科“鼓励运用其他学科的新思想、方法、 成果和先进的设备技术, 研究发生在地球大气中的现象”, 不断吸收人类科技进步的成果. 大气学科重视气象及相关 “灾害事件的发生发展机理及其预报预测研究”, 重视“全 球天气气候和环境变化及其影响、适应和减缓问题”, 重视 “各种过程的综合、集成、系统化、数理建模和模拟研究”, 重视“为民生和社会的可持续发展提供有力科学支持的多学 科交叉研究”, 具有鲜明的服务社会的特点, 是一个充满活 力的学科 ${ }^{[8]}$. 从自身发展来看, 大气学科应适时审视申请 代码与大气科学发展的衔接适应情况, 首先应该考虑的是 代码能否最大限度解放和激发基础研究所蕴藏的巨大潜 能, 以便更好地应对新形势下学科前沿所面临的挑战, 满 足国家和人类社会发展的重大需求.

\section{2 申请代码的定位}

我国目前有 3 种常见的描述自然科学知识体系的代码. 分别为: (1) 中国图书馆分类法(中国图书馆分类词表); (2) 教育部专业代码; (3) 国家自然科学基金申请代码. 虽然这 3 种代码都起到了对知识体系 “分门别类”的功能, 但其设 置初衷却有显著差异. 其中, 自然科学基金申请代码是基 金委为便于项目受理和评审专家遴选, 以学科体系为框 
架 ${ }^{[3]}$, 针对科学研究设置的多层次、综合性的编码体系 ${ }^{[9]}$. 可见, 申请代码不仅面向项目申请和评审, 而且还关系到 学科布局和知识体系. 申请代码不仅要能体现自然科学知 识体系的创新性、前瞻性和融通过程, 同时也要能向科学 界释放基金委资助战略的导向性信号.

要建立适应大气学科发展的申请代码, 框架结构的完 备性和逻辑性是重中之重. 通过前期全面细致的调研工作, 我们清晰地认识到, 现阶段大气学科的申请代码应该包括 “分支学科”、“支撑技术”和“发展领域”三部分. “分支学科” 是知识体系的“骨架和主体”，应保持相对稳定；“支撑技 术”应鼓励先进技术与方法的创新, 从而服务大气科学基 础研究的发展; 而“发展领域”则代表了学科的“肌肉与力 量”, 应与国家经济、社会发展的重大需求紧密衔接. 对于 基金管理而言, 评估申请代码的效能, 不仅要看能否涵盖 “分支学科”、“支撑技术”和“发展领域”, 也应视其是否切实 利于: (1) 申请人准确选择吻合申请书内容的申请代码; (2) 人工智能精确匹配评审专家; (3) 学科状况的辅助分析和 决策.

\section{3 旧版代码存在的主要问题}

2019 年度大气学科申请代码 (表 1 )是在 2008 年度申请 代码的基础上微调而成, 原先的代码倾注了大气科学界的
心血, 并在学科发展过程中发挥过重要作用. 申请代码要 与时俱进, 就需要建立与学科发展相适应的“动态调整机 制”[4], 而大气科学旧版申请代码目前已难以满足新时代 学科发展的需求, 迫切需要改革. 本轮国家自然科学基金 改革引起了广大科研工作者对于学科更深层次的思考, 经 多次研讨发现, 科学界针对大气学科原申请代码反映的问 题集中体现在以下三方面.

\section{1 逻辑结构不自洽}

从原申请代码排序来看, 很难梳理出全局逻辑性, 只 能牵强解释为“并列关系”. 逻辑性不强甚至类别相混, 带 来的不仅是代码顺序问题, 更重要的是可能会通过代码影 响到整个大气学科的资助项目和人才布局, 从而不利于对 学科态势进行分析, 这对学科长远发展是极其不利的.

“分支学科”与“发展领域”混淆. 以“D0513 大气化学 与大气环境”为例, “大气化学”是分支学科, 而“大气环境” 则是“发展领域”. “大气化学”有相对独立的知识体系, 其 内容并非完全面向 “大气环境”; “大气环境”问题的解决, 也不能仅依靠 “大气化学”, 同时还必须依赖于与其他分支 学科(如, 大气动力学、大气物理学、天气学、气候学等) 的交叉融合。

“技术研发”与“技术应用”混淆. 以“D0510数值模式

\section{表 12019 年度基金委大气学科申请代码主要调整方案}

Table 1 Main adjustments on the 2019 version of application codes in the discipline of atmospheric sciences in the National Natural Science Foundation of China

\begin{tabular}{|c|c|c|}
\hline & 二级申请代码 & 调整方案 \\
\hline D0501 & 对流层大气物理学 & 整合到“D0505 大气物理学” \\
\hline D0502 & 边界层大气物理学和大气湍流 & 整合到“D0505 大气物理学” \\
\hline D0503 & 大气遥感和大气探测 & $\begin{array}{l}\text { 技术研发归于“D0509 大气观测、遥感和探测技术与方法”; 技术应用融入“支撑技术” } \\
\text { 和“发展领域”板块 }\end{array}$ \\
\hline D0504 & 中高层与行星大气物理学 & “中高层”归于 “D0505 大气物理学”; “行星”部分在“D0508 行星大气”中单列 \\
\hline D0505 & 天气学与天气预报 & $\begin{array}{l}\text { “天气学”保留; “天气预报”技术研发归于“支撑技术”，技术应用融人“D0501 天气学”, } \\
\text { 及“发展领域”板块 }\end{array}$ \\
\hline D0506 & 大气动力学 & 保留 \\
\hline D0507 & 气候学与气候预测 & $\begin{array}{l}\text { “气候学”归于“D0502 气候与气候系统”; “气候预测”技术研发融人“支撑技术”, 技术 } \\
\text { 应用融人“D0502气候与气候系统”, 及“发展领域”板块 }\end{array}$ \\
\hline D0508 & 气候系统 & 归于“D0502 气候与气候系统” \\
\hline D0509 & 人类活动与气候变化 & 融入“D0502 气候与气候系统”和“D0513 气候变化及影响与应对” \\
\hline D0510 & 数值模式与数值模拟 & $\begin{array}{l}\text { 模式研发归于“D0511 大气数值模式发展”和“D0512 地球系统模式发展”; 数值模拟 } \\
\text { 融人“分支学科”和“发展领域”板块 }\end{array}$ \\
\hline D0511 & 资料同化及应用 & 融入“分支学科”、“支撑技术”、“发展领域”等板块 \\
\hline D0512 & 应用气象学 & 保留 \\
\hline D0513 & 大气化学与大气环境 & “大气化学”保留; “大气环境”归于“D0514 大气环境与健康气象” \\
\hline D0514 & 云雾物理化学与人工影响天气 & $\begin{array}{l}\text { “云雾物理化学”归于“D0505 大气物理学”和“D0506 大气化学”; “人工影响天气”归于 } \\
\text { “D0515 应用气象学” }\end{array}$ \\
\hline D0515 & 大气观测原理、方法及数据分析 & 归于“D0509 大气观测、遥感和探测技术与方法”和“D0510 大气数据与信息科学” \\
\hline
\end{tabular}


与数值模拟”为例, “数值模式”更强调技术研发, 而 “数值 模拟”却强调技术应用. 从实践经验来看, 研发新模式或模 式技术的项目由于挑战性较高, 在函评过程中很难获得共 识, 得分往往偏低; 而纯技术应用的项目, 则往往得分相 对较高. 由于不许“逆序上会”的规定, 将这两部分放在一 起, 不可避免地会导致模式研发较难获得资助机会, 这就 是学科虽然想鼓励针对 “卡脖子”问题的研究, 但时常又显 得力不从心的重要原因.

“三级代码”与“二级代码”混淆. 基金委不提倡代码过 细, 要求 2021 年前所有的学科不再设置三级代码 ${ }^{[10]}$. 大气 学科虽从未设置三级代码, 但部分三级代码却当二级代码 使用. 例如, “D0501 对流层大气物理学”、“D0502 边界层 大气物理学”、“D0504 中高层与行星大气物理学”都是“大 气物理学” 的范畴, 它们本应都是三级代码, 但目前却与二 级代码 “平起平坐”. 这种现象折射出的深层次问题是: 学 科发展的“话语权”不平衡, 强势的二级学科方向可占有多 个代码, 而有的相对小众的、新兴的、弱势的方向却无法 在申请代码中体现应有的地位. 如长此以往, 不设法予以 适当扶持，基础研究的布局势必会出现“短板效应”.

\section{2 分支学科不完整}

从时间尺度来看, 原代码中对有些分支学科的重要性 强调不足. 例如, “古气候”具有独特的变化机制和时间尺 度, 与现代气候具有明显的区别; 美国科学基金会将“古气 候”列为大气学科的重要申请代码 (四大代码方向之一). 原 来的学科代码会引起学者对 “古气候” 的独特性认识不足, 与现代气候混淆. 如果大气学科发展仅满足于就现代气候 论气候, 那么很难对“大气圈层形成与演化”形成深刻认识. 所以“古气候” 恰是大气科学需要关注的核心问题之一, 增 加 “古气候”二级申请代码, 既能体现大气科学的覆盖面, 同时也能体现从地球科学的视角 “以古见今、古为今用”, 使大气科学为整个地球科学的发展作贡献.

从空间尺度来看, 原代码注重研究地球大气的视野太 过局限. 随着人类不断向宇宙空间和其他星系探索, 大气 科学应该将其关注范围拓展至行星大气, “跳出地球看地 球”, 从行星的视角来审视大气科学理论的普适性 ${ }^{[11,12]}$. 从 大气学科的定义来看, 大气科学不仅关注地球大气, 也关 注行星大气. 早在基金委成立之初, “行星大气”就被列人 大气学科申请代码 ${ }^{[13]}$, 但当时大气学科资助体量不足 30 项, 而申请代码却达到 13 个. 这一局面致使“行星大气”这 样的小众方向难以维系, 结果导致在后续的代码调整过程 中非常遗憾地被取消掉了. 而目前看来, 在资助体量和研 究手段都比 30 年前有了质的飞跃的今天, 正是“行星大气” 这一代码回归, 实现中国大气科学界先辈们初心和夙愿的 大好时机.

从与母学科的关系来看, 气象学与数学、力学、物理 学、化学等学科交融, 分别催生了独立的分支学科一大
气动力学、大气物理学、大气化学等, 而没有以生态学与 生物学作为母学科的分支学科. 传统气象学与生态的联系 主要限于“农业气象”, 而现代大气科学中强调包括生物圈 在内的气候系统多圈层相互作用. 因此, “生态气象”应有 更广泛的含义, 不仅是农作物, 还要涉及整个生态系统. 大气圈与生物圈的相互作用亟待加强 ${ }^{[14]}$, 否则至少会导致 两方面不利后果：一方面，大气学科对生态文明建设等国 家重大需求的基础理论供给不足, 无法在生态安全领域起 到减灾防灾“第一道防线”的作用; 另一方面, 生物过程本 身就是大气变化中的一个重要的基础过程, 大气并非只是 单向对生物圈产生影响, 反过来生物圈可通过影响地气交 换而改变大气的成分, 还可以影响边界层动力过程, 甚至 生物气溶胶还能参与云物理等大气内部过程. 显而易见, 目前这些知识的缺乏在客观上不可避免地会对大气学科 的自身发展形成制约.

\section{3 与地球科学顶层设计脱节}

从新时代资助导向来看, 原代码已不能完全体现“交 叉融通”和“需求汼引”的资助导向. 大气科学的诞生本身 就是学科交叉融合的结果, 除了如上所述的时空尺度以及 分支学科与母学科的交融关系之外, 大气科学与社会科学 的交叉也严重不足, 而当前最新的与大气科学相关联的国 际科学计划——未来地球”, 强调的就是自然科学与人文 科学的交叉融合 ${ }^{[15,16]}$. 交叉融通不够, 往往会造成知识在 服务社会的传递过程中出现短链或断链的现象.

从“宜居地球”之“三深一系统”战略设计来看, 原代码 的资助实践与“深海”融合相对较好, 而与“深地”、“深空” 对接却严重不足, 对“地球系统”的支撑作用也强调得不够. 我们通过深人广泛的调研发现，甚至持有“大气科学与 “三 深”无关”片面观点的科学家亦不在少数, 对大气科学在“地 球系统科学” 中的作用认识不足可见一斑. 如不及时扭转 这一趋势, 就很可能导致大气学科在“三深一系统”资助框 架下处于非常不利的位置.

\section{4 调整过程与措施}

申请代码作为学科布局顶层设计的重要内容之一, 必 须要能够同时体现紧扣学科的“内涵”、“外延”以及“在国家 和人类社会发展中的历史使命”这三大要点. 代码修订过 程中学科须着重把握: (1) 政策导向要鲜明. 学科要能精准 理解改革的要义, 准确向科学界传递基金委和学部顶层设 计的精神, 把握政策导向. (2) 关键少数要给力. 为做好本 次工作, 学科提前布局了战略研究项目组, 并成立了科学 顾问组, 邀请战略专家领衔战略研究并担任科学顾问, 主 要任务是把握学术方向并形成代表科学界的政策建议. (3) 群众基础要广泛. “理念是否深人人心”关系到改革成败, 因此政策宣讲、调研以及调动广大科学家踊跃参与的积极 
性尤为重要. 通过深人全面开展上述三方面的工作, 申请 代码框架设计比原来更为清晰, 代码表述亦越来越严谨, 最终形成了申请代码应从“分支学科” 人手, 再到“支撑技 术”, 最终到“发展领域”三大有序模块的共识, 有力助推大 气科学从传统“气象学”向与“地球系统科学”相适应的转变. 通过调整, 2020 年度大气学科申请代码数 (表 2)与 2019 版总 数持平, 但调整后内容的体系性和结构性均有了显著提高 (图1). 主要调整内容如下.

\section{1 “分支学科”一构建“双维度、互融合”的有机结 构体系}

“分支学科”共设 8 个代码, 占总代码数的 $53 \%$, 依次 为: “D0501 天气学”、“D0502 气候与气候系统”、“D0503 古气候学”、“D0504 大气动力学”、“D0505 大气物理学”、 “D0506 大气化学”、“D0507 生态气象”, “D0508 行星大气”.

从时间尺度的维度上, 分为“D0501 天气学”、“D0502 气候与气候系统”、“D0503 古气候学”3 个代码. 如此一来, 可从“分钟、小时”直至“地史”的时间尺度, 系统研究大气 运动的规律和演变, 使得大气科学研究既能从当前的局部 “以小见大”, 又能在历史长河中审视当前的问题, 从而助 力大气科学建立能同时统辖这三大时间尺度的理论体系. 这也正是大气科学基础研究的重要目标. 需要说明的是, 虽然从表述上, “气候学”比“气候与气候系统”更能与“天气 学” 和 “古气候学” 相对应, 但考虑到当今气候研究对象已 从单纯的气候态 (天气的平均状态) 走向气候系统, 同时也 为了回应大气科学界呼吁的加强 “多圈层相互作用”, 虽然 表面上从代码的简洁性上做出了一定牺牲, 但同时却强调
了更为倚重的申请代码的导向性. 大气学科的“古气候学” 区别于其他学科的古气候研究在于 “4 个侧重”, 数据描述 上更侧重“面”，理论研究上更侧重“大气环流”，技术手段 上更侧重“数值模拟”与“现代统计方法”等定量化手段, 研 究目标上更侧重“古为今用”.

从母学科的视角, 设置“D0504 大气动力学”、“D0505 大气物理学”、“D0506 大气化学”、“D0507 生态气象”、 “D0508 行星大气” 5 个代码, 分别疏浚了数学与力学、物 理学、化学、生态学与生物学、天文学与行星科学等母学 科与大气科学交叉融合的通道. 大气学科最早是以现象描 述为主的学科, 但自走上“精深数理化”的发展道路, 实现 了定量描述和预报, 最终使得大气科学发展成为了一门独 立的现代科学. 由此可见, 只有使母学科的知识成果能够 顺利进人大气科学, 才能使大气科学在理论体系上获得强 大的源头动力. 考虑到“生态气象”与“行星大气”尚未像其 他分支学科那样已形成具有系统性的知识体系, 故暂不加 “学”字, 但通过本次代码的调整势必能够催化二者向分支 学科方向演进, 终将形成“生态气象学”与 “行星大气学”, 对此科学界颇有信心.

从“时间尺度”和“母学科”两个维度设置分支学科, 使 得各分支学科间不再相对孤立，十分有利于分支学科间互 相融合. 以“天气学”为例, 天气过程不仅与 “大气动力学” 密切相关, 同时还涉及“大气化学”、“大气物理学”等分支 学科, 故“天气学”可推动具有不同母学科背景的分支学科 之间相互融合. 再以“大气动力学”为例, 由于其能统辖“天 气”、“气候”、“古气候”大气动力理论, 故这些不同时间尺 度的分支学科可在动力学的观点下进行融合.

\section{表 22020 年度基金委大气学科申请代码及相关说明}

Table 2 Application code system in 2020 and related instructions in the discipline of atmospheric sciences in the National Natural Science Foundation of China

\begin{tabular}{|c|c|c|c|}
\hline 二级申请代码 & 说明 & 板块 & 注意事项 \\
\hline D0501 天气学 & & \multirow{8}{*}{$\begin{array}{l}\text { 分支 } \\
\text { 学科 }\end{array}$} & \multirow{8}{*}{$\begin{array}{l}\text { 重在自然科学基础理论研究, 申请书 } \\
\text { 应围绕地球和行星大气中发生的各 } \\
\text { 种现象及其变化规律的新认知, 布 } \\
\text { 局关键科学问题 }\end{array}$} \\
\hline D0502 气候与气候系统 & 从“分钟”等短时尺度至“地史”尺度 & & \\
\hline D0503 古气候学 & & & \\
\hline D0504 大气动力学 & 母学科: 数学与力学 & & \\
\hline D0505 大气物理学 & 母学科: 物理学 & & \\
\hline D0506 大气化学 & 母学科: 化学 & & \\
\hline D0507 生态气象 & 母学科: 生物与生态学 & & \\
\hline D0508 行星大气 & 母学科: 天文与行星科学 & & \\
\hline D0509 大气观测、遥感和探测技术与方法 & 观测技术 & \multirow{4}{*}{$\begin{array}{l}\text { 支撑 } \\
\text { 技术 }\end{array}$} & \multirow{4}{*}{$\begin{array}{l}\text { 以发展具有中国自主知识产权的新技 } \\
\text { 术与新方法为根本目的. 基于现有 } \\
\text { 技术开展理论或应用研究的申请不 } \\
\text { 适于填报此类代码, 而应选择其他 } \\
\text { 两类代码 }\end{array}$} \\
\hline D0510 大气数据与信息科学 & 数据技术 & & \\
\hline D0511 大气数值模式发展 & \multirow[b]{2}{*}{ 模式技术 } & & \\
\hline D0512 地球系统模式发展 & & & \\
\hline D0513 气候变化及影响与应对 & “减灾”、“经济”和“管理”等领域 & \multirow{3}{*}{$\begin{array}{l}\text { 发展 } \\
\text { 领域 }\end{array}$} & 重在利用大气科学知识和理论服务国 \\
\hline D0514 大气环境与健康气象 & “环境保护”和“公共健康”等领域 & & 家和社会发展的重大需求, 促进基 \\
\hline D0515 应用气象学 & 其他相关领域 & & 础研究和应用研究间的融合 \\
\hline
\end{tabular}




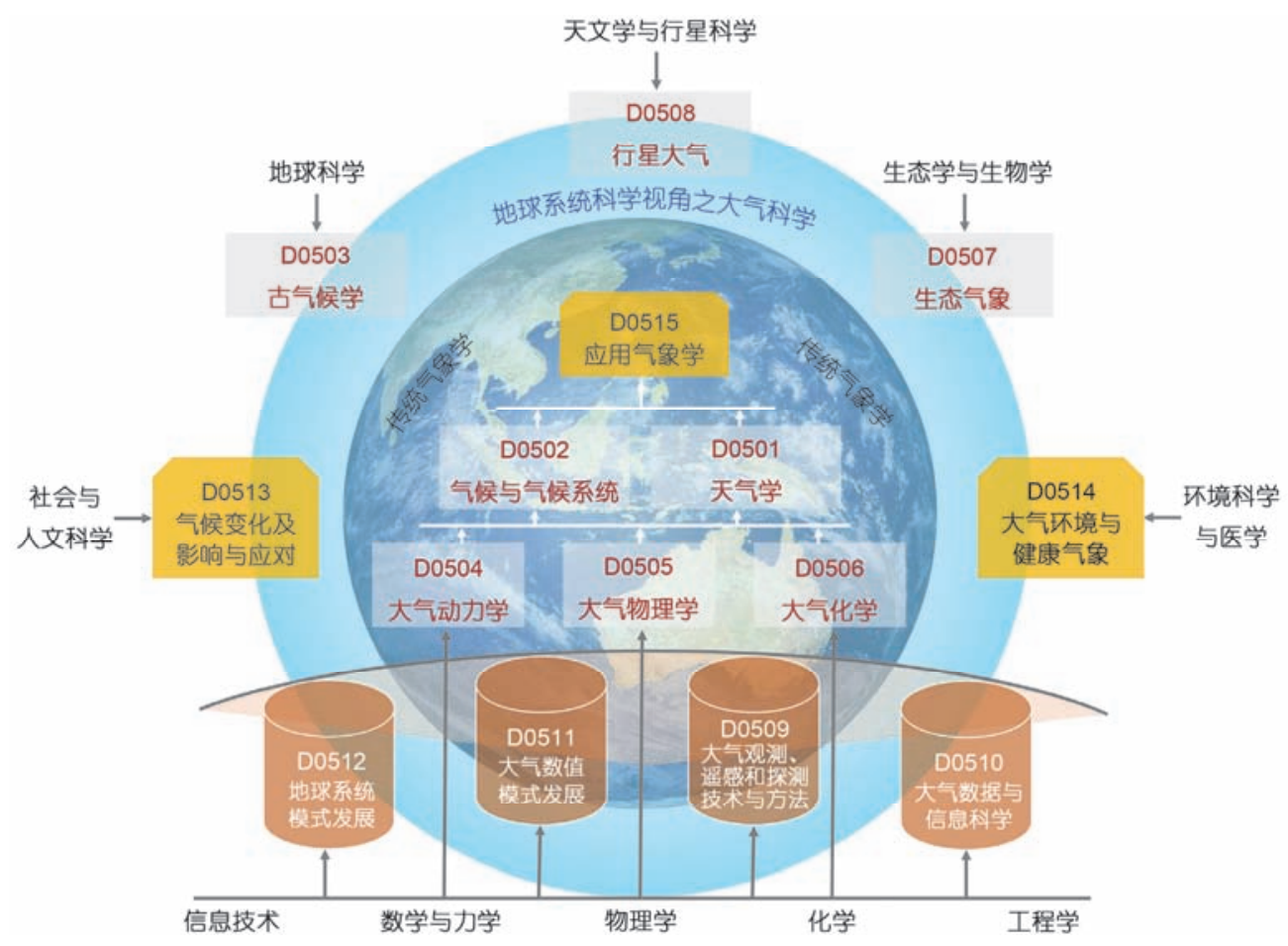

图 12020 版基金委大气学科代码设置总体思路示意图. 其中, 内、外圈分别代表 “传统气象学”和“地球系统科学视角下的大气科学”; 灰 框红字为“分支学科”，棕柱白字为“支撑技术”, 黄框黑字为“发展领域”, 外围黑色文字为相关联的母学科; 箭头体现代码间逻辑结构及大 气学科与其他学科间的交叉关系

Figure 1 Overall framework of the 2020 version of NSFC application codes in the discipline of atmospheric sciences. The inner and outer rings represent "traditional meteorology" and "atmospheric sciences under the perspective of earth system sciences", respectively. The gray boxes, brown columns and yellow boxes stand for "branch disciplines", "supporting technologies", and "social development services", respectively. The arrows inside the inner ring indicate the logical structure of the application codes. The disciplines of mother sciences are listed outside the outer ring in black, with the arrows pointing to the related codes

\section{2 “支撑技术”一一培育自主知识产权的技术与方法}

“支撑技术”共设置 4 个代码, 占总代码数的 $27 \%$. 从 数据获取与分析的技术手段上, 分别设置“D0509 大气观 测、遥感和探测技术与方法”、“D0510 大气数据与信息科 学”、“D0511 大气数值模式发展”和“D0512 地球系统模式 发展”.

同地球科学的其他分支学科一样, 大气科学亦是以观 测数据为基础的学科. 但在用词上, 大气科学又有别于地球 科学的其他分支学科, 习惯性分为“探测”、“遥感”和“观 测” (狭义的观测, 特指基于观测者主观记录的实验和实验室 内开展的器测实验). 考虑到业界习惯, 学科没有将三者合 并为 “观测”一词, 以免申请人填报申请书时产生不必要的 误会. “大气数据与信息科学”除包括传统的大气数据分析技 术外, 更强调在大气数据处理分析中利用“大数据技术”、 “人工智能”等新兴技术 ${ }^{[17]}$. “大气数值模式发展”和“地球系 统模式发展”虽然都是 “模式”, 但内涵却迥然不同. 在地球 系统科学的整体框架下, 前者面向大气科学分量模式技术 的研发, 而后者则是包括大气在内地球系统各分量模式的 耦合. 在地球科学领域, 大气学科一直都在数值模式和定量
预测方面起着引领作用, 地球系统模式的研发也一直在由 大气科学来主导承担. “模式发展”一词源于“model development”, 它强调具有自主知识产权的模式研发而非模式(模 拟)应用, 这也正是我国大气科学发展长期存在的“卡脖子” 的核心技术. “数据同化”虽未显含在申请代码中, 但却在所 有“支撑技术”类代码的“研究方向”及其下设关键词中多次出 现. 显然, “数据同化”不仅没有被弱化, 反而被加强了.

需要强调的是, “支撑技术”类代码服务于中国自主知 识产权的技术研究. 纯技术应用类研究不适合填报此类型 代码，而应从“分支学科”或“发展领域”中选择相应的代码， 大气学科鼓励具有相关背景的技术人才与大气科学家合作, 共同致力于大气科学基础研究关键技术的研发, 特别是对 “卡脖子”关键技术和具有“颠覆性”的引领技术的突破.

\section{3 “发展领域”一一应对国家和人类社会发展重大 需求}

“发展领域”共设置 3 个代码, 占代码总数的 $20 \%$, 包 括“D0513 气候变化及影响与应对”、“D0514 大气环境与健 康气象”和“D0515 应用气象学”。 
“气候变化及影响与应对”引导大气科学家在研究全 球气候变化的同时, 注重与 “社会科学”交叉, 关注气候变 化的经济、社会影响与效应, 积极思考应对措施, 服务于 国家和人类社会发展中的减灾防灾战略, 同时为国家和人

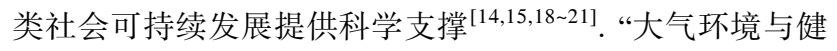
康气象”与原代码 “大气环境”相比, 更能引导、鼓励大气科 学家在研究大气成分变化的同时, 积极与“医学”等领域交 叉, 关注大气环境变化的健康效应, 并以此为基础助力国 家气象和环境等部门形成更多的预报产品, 贴近百姓生 活 ${ }^{[22,23]}$. “应用气象学”主要包括“人工影响天气”、“农林气 象”、“水文气象”、“资源气象”、“交通气象”、“其他应用 气象” 等方向, 旨在引导大气科学知识有效服务于其他行 业部门, 从而为国家社会的发展趋利避害.

针对部分研究内容兼具理论与现实意义的申请书如 何更准确地选择申请代码的问题, 以“农业气象”研究为例, 如果申请书内容更多关注大气圈层与生态系统在物质、能 量、信息上的互馈过程, 侧重基础研究, 则申请代码优先 选择“D0507 生态气象”. 若申请书更侧重利用生态气象的 基础知识, 服务于农业生产过程, 那么应该申请代码可优 先选择“D0515 应用气象学”.

需要指出的是, 在国家和人类社会发展的不同时期, 对于大气科学基础研究的需求有着不同的侧重点. 因此, 在 “发展领域”内的申请代码, 要紧扣时代发展的需求进行 动态调整. 事实上, “发展领域”的本质就是把“分支学科” 和“支撑技术”相关领域的知识转移到社会发展服务上来, 不断满足国家和人类社会发展的新需求和前瞻性需求, 这 也正是大气科学充满无限生命力的原因所在.

\section{4 “论证过程”一一自上而下”与“自下而上”相结合}

自 2019 年 3 月以来, 基金委大气学科依托各类评审 会、学科工作会议、战略研讨会等, 组织专家近 200 人次 共商学科申请代码调整问题. 同时依托战略研究项目, 认 真梳理了大气科学前沿及发展态势, 深人研究了美国国家 科学基金会大气学科资助结构 ${ }^{[24]}$, 并向业务单位诸多专家 问计国家发展需求. 在学科、战略研究组及科学顾问、广
大科学界不断互动的过程中, “上下”有机结合, 广泛深人 研讨, 最终形成了申请代码调整方案. 在此过程中, 大气 学科工作人员还以 2019 年度面上项目申请书为例, 按照 设计方案通过代码选择的路演模拟操作, 发现新代码逻辑 性更强、包容性更广, 能够极大程度地方便申请人顺利找 到最合适的申请代码. 2019 年 10 月, 基金委“地球科学部 第七届专家咨询委员会第 6 次会议”论证并通过了大气学 科申请代码调整方案, 后经部务会同意, 报分管委领导批 准并由计划局核准后, 列人 《2020 年度国家自然科学基金 项目指南》.

专家们一致认为, 调整后的学科申请代码能更好地贯 彻落实“新时代科学基金资助导向”, 主要亮点在于: (1) 充 分体现了大气学科的内涵与外延, 与《国家自然科学基金 项目指南》吻合, 有助于推动大气学科发展; (2) 申请代码 的包容性和覆盖面明显提高, 加强了对跨学科大交叉研究 的支持, 符合基金委相关文件的要求，契合学科布局改革 任务的精神; (3) 通过增设“古气候学”、“行星大气”、“地球 系统模式发展”等代码, 使得大气科学更好地与“深地”、“深 空”融合, 并为地球系统科学提供更好的定量化研究平台, 实现了与“宜居地球”之“三深一系统”顶层战略设计的对接.

\section{5 结束语}

申请代码调整应基于明确的“问题导向”, 原代码无法 完全适应大气学科发展的内在和外在需求, 而代码调整方 案的探索路径本身就是落实新时代科学基金资助导向的 过程，体现了国家自然科学基金优化大气学科资助布局的 理念、决心和信心. 新申请代码设置方案是科学共同体智 慧的结晶, 既展现了科学界的共识, 又体现了大气科学衔 接“三深一系统”的发展理念, 也凝聚着大气科学领域专家 对科学基金工作的理解、信任和支持.

在学科申请代码调整的基础上, 大气学科已组织多轮 研讨，规划代码下设的“研究方向”及“关键词”, 至此形成 从“代码”到“研究方向”再到“关键词”的完整信息链条, 并 已在基金委信息中心的协助下更新评审专家库，为 2020 年度项目申请和智能指派做充分准备.

致谢衰心感谢国家自然科学基金委员会大气学科发展战略研究项目科学顾问组、地球科学部咨询委员会、相关研讨 会的与会专家、函询专家们对本次申请代码调整工作的鼎力支持, 他们所提的宝贵意见和建议是这次申请代码 调整工作得以顺利进行的基础保障; 特别感谢国家自然科学基金委员会大气科学发展战略研究项目组全体成员 以及国家自然科学基金委员会大气学科流动编制和兼聘工作人员，本文的研究成果离不开他们大量细致的调 研、数据统计分析等辛劳的工作; 本次申请代码调整工作自始至终都得到了国家自然科学基金委员会分管委领 导、地球科学部领导一如既往的关心和悉心指导，也得到了国家自然科学基金委员会计划局、政策局和信息中 心的大力支持, 作者在此一并表示诚挚的感谢! 


\section{推葆阅读文献}

1 National Natural Science Foundation of China. National Natural Science Fund Guide to Programs 2019 (in Chinese). Beijing: Science Press, 2019. 316 [国家自然科学基金委员会. 2019 年度自然科学基金项目指南. 北京: 科学出版社, 2019. 316]

2 Li J H. Building a science funding system for a new paradigm shift in science (in Chinese). Bull Natl Nat Sci Found Chin, 2018, 32: 345-350 [李静海. 构建新时代科学基金体系夯实世界科技强国根基. 中国科学基金, 2018, 32: 345-350]

3 Li J H. Review and prospect on National Natural Science Fund supporting China's basic research (in Chinese). Bull Chin Acad Sci, 2018, 33: 390-395 [李静海. 国家自然科学基金支持我国基础研究的回顾与展望. 中国科学院院刊, 2018, 33: 390-395]

4 National Natural Science Foundation of China. Notice of the Issuance of Action Plan of NSFC on Promoting the Role of Scientific Foundation in China's Science and Technology Innovation System (in Chinese). National Natural Science Foundation of China, 2019, No. 56 [国 家自然科学基金委员会. 关于印发《国家自然科学基金委员会关于更好发挥科学基金在我国科技创新体系中作用的行动方案》的 通知(国科金发计 2019[56 号])]

5 China Association for Science and Technology, Chinese Meteorological Society. Report on Advances in Atmospheric Science 2009-2010 (in Chinese). Beijing: China Science and Technology Press, 2010. 134 [中国科学技术协会, 中国气象学会. 2009 2010大气科学学科 发展报告. 北京: 中国科学技术出版社, 2010. 134]

6 Huang R H, Wu G X, Chen W, et al. Major Scientific Issues in Atmospheric Science and Global Climate Change Research (in Chinese). Beijing: Science Press, 2016 [黄荣辉, 吴国雄, 陈文, 等. 大气科学和全球气候变化研究重大科学问题. 北京: 科学出版社, 2016]

7 National Natural Science Foundation of China, Chinese Academy of Sciences. China's Discipline Development Strategy—Atmospheric Sciences (in Chinese). Beijing: Science Press, 2016 [国家自然科学基金委员会, 中国科学院. 中国学科发展战略一一大科学. 北京: 科学出版社, 2016]

8 Wang H J, Xu Y F, Zhou T J, et al. Atmospheric science: A vigorous frontier science (in Chinese). Adv Earth Sci, 2004, 19: 525-532 [王 会军, 徐永福, 周天军, 等. 大气科学: 一个充满活力的前沿科学. 地球科学进展, 2004, 19: 525-532]

9 Liu Q, Zhu W T, Chen Z. Characteristics and implications of foreign science foundation application code (in Chinese). Bull Natl Nat Sci Found Chin，2007，21：190-192 [刘权，朱蔚彤，陈钟. 国外科学基金组织项目申请代码特点及其启示. 中国科学基金，2007，21： 190-192]

10 National Natural Science Foundation of China. Notice of the Issuance of Action Plan of Optimizing Layout of Funding Systems: Stage I (in Chinese). National Natural Science Foundation of China, 2019, No. 73 [国家自然科学基金委员会. 关于印发《科学基金学科布局改 革任务第一阶段工作实施方案》的通知(国科金政函 2019[73 号])]

11 Ip W H. New insights to the planetary formation process (in Chinese). Chin Sci Bull, 2016, 61: 1758-1761 [叶永烜. 行星形成. 科学通 报, 2016, 61: 1758-1761]

12 Hu Y Y, Tian F, Liu J J. A review on planetary atmospheric research. In: Huang R H, Wu G X, Chen W, et al., eds. Advances and Frontiers in Atmospheric Science and Global Climate Change Research (in Chinese). Beijing: Science Press, 2014. 290 -333 [胡永云，田丰， 刘钧钧. 行星大气研究进展综述. 见: 黄荣辉, 吴国雄, 陈文, 等, 编. 大气科学和全球气候变化研究进展与前沿. 北京: 科学出版社, 2014. 290-333]

13 National Natural Science Foundation of China. National Natural Science Fund Guide to Programs 1988 (in Chinese). Beijing: Science Press, 1988. 162 [国家自然科学基金委员会. 1988 年度自然科学基金项目指南. 北京: 科学出版社, 1988. 162]

14 Fu C B, Manton M. Review of the Monsoon Asia Integrated Regional Study (MAIRS) Program over the past 10 years (in Chinese). Chin J Atmos Sci, 2018, 42: 524-532 [符淙斌, Manton M. 季风亚洲区域集成研究国际计划(MAIRS)10 年回顾. 大气科学, 2018, 42: 524-532]

15 Future Earth. Global Research Projects 2015 Summary. Future Earth-Research for Global Sustainability, 2015

16 Zhou T J, Chen X L, Wu B. Frontier issues on climate change science for supporting Future Earth (in Chinese). Chin Sci Bull, 2019, 64: 1967-1974 [周天军，陈晓龙，吴波. 支撑“未来地球”计划的气候变化科学前沿问题. 科学通报, 2019, 64: 1967-1974]

17 Guo H D, Wang L Z, Cheng F, et al. Scientific big data and digital earth (in Chinese). Chin Sci Bull, 2014, 59: 1047-1054 [郭华东, 王 力哲, 陈方, 等. 科学大数据与数字地球. 科学通报, 2014, 59: 1047-1054]

18 Ye D Z, Fu C B, Dong W J, et al. Some advance in global change science study (in Chinese). Chin J Atmos Sci, 2003, 27: 435-450 [叶笃 正, 符淙斌, 董文杰, 等. 全球变化科学领域的若干研究进展. 大气科学, 2003, 27: 435-450]

$19 \mathrm{Xu} \mathrm{G} \mathrm{H}$, Ge Q S, Gong P, et al. Societal response to challenges of global change and human sustainable development (in Chinese). Chin Sci Bull, 2013, 58: 2100-2106 [徐冠华, 葛全胜, 宫鹏, 等. 全球变化和人类可持续发展：挑战与对策. 科学通报, 2013, 58: 2100-2106]

20 Zeng Q C. Monitoring, prediction and management of meteorological disasters (in Chinese). Chin Sci Bull, 2017, 62: 1315-1323 [曾庆存. 进一步提高气象灾害的监测、预测和防控调度能力的前景. 科学通报, 2017, 62: 1315-1323]

21 Huang L, Zhang Y X, Chao Q C, et al. Suggestions on China's capacity building in response to climate change in the "post-Paris" era (in Chinese). Chin Sci Bull, 2020, 65: 373-379 [黄否, 张永香, 巢清尘, 等. “后巴黎”时代中国应对气候变化能力建设方向. 科学通报, 2020, 65: 373-379]

22 Cui X Q, Cai W S, Shi X M, et al. The nature and scale of the response to climate change will determine the health for centuries to come in China (in Chinese). Chin Sci Bull, 2020, 65: 12-17 [崔学勤，蔡闻佳，施小明，等. 当前应对气候变化的力度决定未来中国的公众 健康水平. 科学通报, 2020, 65: 12-17]

23 Zhong S, Huang C R. Climate change and human health: Risks and responses (in Chinese). Chin Sci Bull, 2019, 64: 2002-2010 [钟爽, 黄存瑞. 气候变化的健康风险与卫生应对. 科学通报, 2019, 64: 2002-2010]

24 National Science Foundation. Strategic Guidance for the National Science Foundation's Support of the Atmospheric Sciences. Washington DC: The National Academies Press, 2007 


\title{
Adjusting application codes and optimizing funding layout for the discipline of atmospheric sciences in the National Natural Science Foundation of China
}

\author{
Zhe Liu ${ }^{1 *}$, Aijun Ding ${ }^{2} \&$ Renhe Zhang ${ }^{3}$ \\ ${ }^{1}$ Department of Earth Sciences, National Natural Science Foundation of China, Beijing 100085, China; \\ ${ }^{2}$ School of Atmospheric Sciences, Nanjing University, Nanjing 210023, China; \\ ${ }^{3}$ Department of Atmospheric and Oceanic Sciences \& Institute of Atmospheric Sciences, Fudan University, Shanghai 200438, China \\ *Corresponding author, E-mail: liuzhe@nsfc.gov.cn
}

The National Natural Science Foundation of China (NSFC) launched the Reform Initiatives, and defined three major reform tasks under the guidance of the overall goal of building a national natural science funding system in the new era. One of the three tasks under this goal is to optimize the funding layout in order to support convergence between knowledge and application according to the inherent logic and landscape of the knowledge systems. The application code system of NSFC is of vital importance to its funding strategy and provides strong guidelines for the disciplinary layout.

In 2019, the discipline of atmospheric sciences (DAS) was selected as a reform pilot in the Department of Earth Sciences (DOE) of NSFC. Based on "problem orientation", the application code system was reviewed and significantly revised according to the top-level strategy of "Habitable Earth", initiated by DOE. The "Habitable Earth" strategy is dedicated to promote the geosciences within the frame of Earth System Sciences, with emphasis on "deep earth", "deep sea”, and "deep space”. In this study, the background for the code system adjustment is addressed, the reform idea and measurements are illustrated, and the structures of the new code system are set up, which are helpful for the applicants to select the appropriate codes in their proposals, and beneficial to the scientific community to better understand the future funding layout of DAS.

After in-depth analysis of previous application code system, several key drawbacks are pointed out. They are but not limited to: (1) Lack of self-consistency in logical structures, (2) incomplete coverage of sub-disciplines, and (3) disconnection with the strategy of "Habitable Earth". To address these issues, this paper proposes a new classification strategy for the application codes according to three coordinated aspects: (1) Branch disciplines, (2) supporting technologies, and (3) social development services. The effective promotion of the integration of atmospheric sciences within "Habitable Earth" is proposed by establishing cross-disciplinary codes for interdisciplinary sciences. The proposed new code system in DAS consists of 15 sub-codes, i.e., "D0501 Synoptic Meteorology", "D0502 Climate and Climate System", "D0503 Paleoclimatology", "D0504 Atmospheric Dynamics", "D0505 Atmospheric Physics", "D0506 Atmospheric Chemistry", "D0507 Ecological Meteorology”, "D0508 Planetary Atmosphere”, "D0509 Atmospheric Observation Techniques", "D0510 Atmospheric Data and Information Science”, "D0511 Atmospheric Numerical Model Development", "D0512 Earth System Model Development", "D0513 Climate Change, its Impacts and Countermeasures", "D0514 Atmospheric Environment and Medical Meteorology", and "D0515 Applied Meteorology". The first eight items (D0501 to D0508), the next four items (D0509 to D0512), and the last three items (D0513 to D0515) are categorized as "branch disciplines", "supporting technologies", and "social development services", respectively.

Based on the adjusted application code system, the "research directions" for each code as well as "keywords" for each direction are determined. Finally, a complete information chain for the discipline of atmospheric sciences is formed, consisting of "application codes", "research directions", and "keywords". The expert information in the DAS database has begun to be updated according to the new chain. The information in the new chain will be also conducive to the application of artificial intelligence technology in assigning the proposals to appropriate reviewers and classifying the research achievements in DAS.

The efforts to adjust the application codes reflect the consensus of the broad atmospheric sciences community on the development of atmospheric sciences from "traditional meteorology" to the concept of "Habitable Earth", as well as embody NSFC's funding orientation in the new era of China.

\section{National Natural Science Foundation of China, application codes, atmospheric sciences, earth system sciences}

doi: 10.1360/TB-2020-0146 